\title{
Typification of three names in Garcinia (Clusiaceae)
}

\author{
Arun Prasanth R., Karun Wilson \& Velusamy Sundaresan* \\ Department of Plant Biology and Systematics. \\ CSIR-Central Institute of Medicinal and Aromatic Plants, \\ Research Centre, Bangalore - 560 065, India. \\ *E-mail: vsundaresan@cimap.res.in
}

\begin{abstract}
Lectotypes for two names Garcinia gummigutta (L.) N.Robson var. conicarpa (Wight) N.P.Singh and G. gummi-gutta (L.) Robson var. papilla (Wight) N.P.Singh are designated here. The second step lectotypification is done for the name Garcinia indica (Thouars) Choisy. The detailed nomenclature notes and images of type specimens are provided.
\end{abstract}

Keywords: Clusiaceae, Endemic, Garcinia, India, Nomenclature, Typification.

\section{Introduction}

The tropical genus Garcinia L. (Clusiaceae) comprises nearly 250 species (Mabberley, 2017) in the world. The genus is represented by c. 35 species in India (Maheshwari, 1964; Singh, 1993). During a revision of Garcinia in India, we found the necessity of typification of two varietal names viz., Garcinia gummi-gutta var. conicarpa (Wight) N.P.Singh and Garcinia gummi-gutta var. papilla (Wight)N.P.Singh and second step lectotypification of the name Garcinia indica (Thouars) Choisy. After consulting the protologues and types and other relevant specimens at $\mathrm{A}, \mathrm{ADB}, \mathrm{B}, \mathrm{BM}, \mathrm{BR}, \mathrm{CAL}$, $\mathrm{G}, \mathrm{K}, \mathrm{L}, \mathrm{MH}$ and $\mathrm{P}$, lectotypes have been designated here according to Art. 9.3 and Art. 9.17 of ICN (Turland et al., 2018). Epitypes for Garcinia gummigutta var. papilla and Garcinia indica are also designated following Art. 9.9 of ICN (Turland et al., 2018).

Garcinia gummi-gutta (L.) N.Robson var. conicarpa (Wight) N.P.Singh in B.D.Sharma \&

Received: 25.08.2019; Revised \& Accepted: 10.12.2019

Published Online: 31.12.2019
Sanjappa, Fl. India 3: 110. 1993. Garcinia conicarpa Wight, Ill. Ind. Bot. 1: t. 121. p. 126. 1839. Lectotype (designated here): INDIA, Tamil Nadu, Shevagherry hills, 08.1836, R. Wight 141 (K000677578 digital image!; isolecto K000677579, K000677580 digital images!)

Fig. 1

Notes: Wight (1839) described Garcinia conicarpa Wight, with an illustration based on his collection from Shevagherry hills. Anderson (1874) reduced this species as a variety G. cambogia var. conicarpa (Wight) T.Anderson. Singh (1993) in his revision of Indian

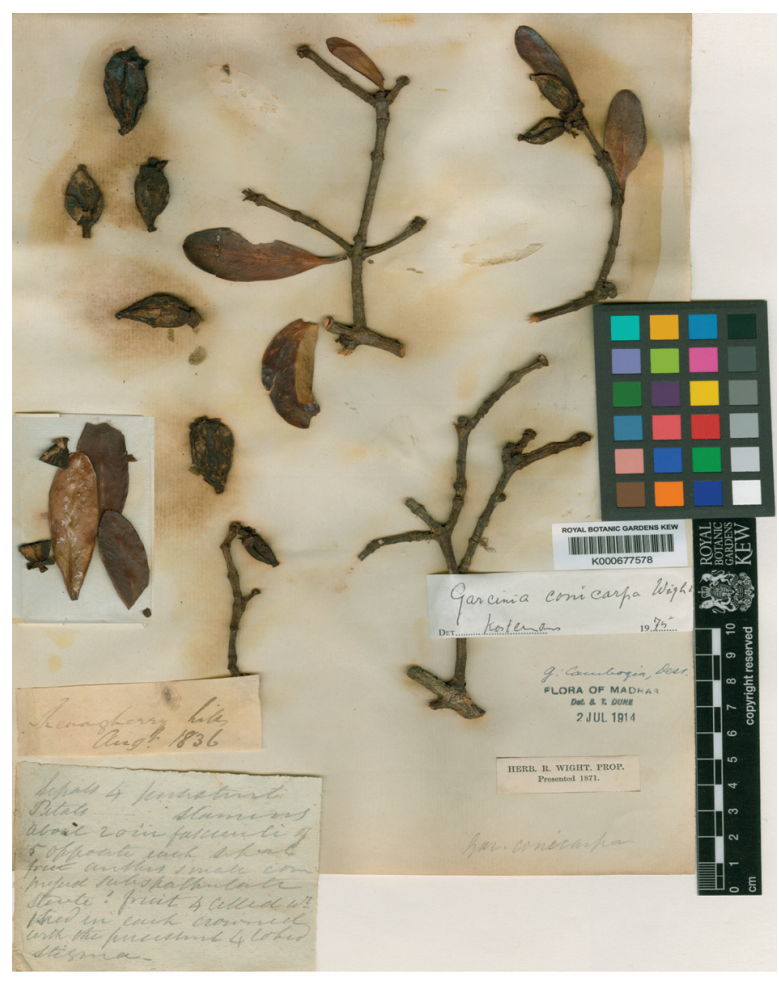

Fig. 1. Lectotype of Garcinia gummi-gutta (L.) N.Robson var. conicarpa (Wight) N.P.Singh (Wight141, K000677578) (C) The Board of Trustees of the Royal Botanic Gardens, Kew. 
Garcinia treated this taxon as a variety of G. conicarpa under G. gummi-gutta. According to Stafleu and Cowan (1988) herbarium and types of Wight's names are at K, E and further materials at A, ADB, B. Authors could trace three specimens of Wight from Shevagherry hills collected on August 1836 with the no. 141 (K000677578, K000677579), 249 (K000677580) and the same was cited as syntype by Noltie (2005) in his book 'The Botany of Robert Wight'. But the specimens from Ceylon (Male) cited in protologue could not be traced. Another specimen of G. conicarpa collected on January 1845 from Shevagherry hills with the no. 142 could be traced at $\mathrm{K}$ (K00677577) and the duplicate at CAL (CAL0000024972). Maheshwari (1964) cited a CAL specimen (probably CAL0000024972) as the type. Since this specimen is not a part of original material, the specimen 'Wight 141' from Shevagherry hill at $\mathrm{K}$ (K000677578) is designated here as the lectotype of G. conicarpa.

Garcinia gummi-gutta (L.) N.Robson. var. papilla (Wight) N.P.Singh in B.D.Sharma \& Sanjappa, Fl. India 3: 111. 1993. Garcinia papilla Wight, Icon. Pl. Ind. Orient. 3(3): 4. t. 960, 960/2. 1845. Lectotype (designated here): Wight's Illustration in Icones Plantarum 3: 960/2, 1845, (female); Epitype (designated here): INDIA, Kerala, Cochin, 04.1848, Wight 143 (K001273085 digital image!).

Notes: Wight (1845) described and illustrated Garcinia papilla based on his collections from Conoor and Sispara. Singh (1993) reduced it as a variety G. gummi-gutta var. papilla (Wight) N.P.Singh. According to Stafleu and Cowan (1988) major part of Wight's collection is available in $\mathrm{K}$, $\mathrm{E}$ and further materials at $\mathrm{A}, \mathrm{ADB}$ and $\mathrm{B}$. According to Noltie (2005) no possible type for this name is available in $\mathrm{K}$ and $\mathrm{E}$. We searched in $\mathrm{K}, \mathrm{E}, \mathrm{A}, \mathrm{ADB}$, $\mathrm{B}, \mathrm{L}$ through virtual database and consulted CAL and MH. Maheshwari (1964) in his revisionary work of Indian Guttiferae III, mentioned "Type: Wight Conoor and Sisparah jungles, Nilgiri (K)" and considered the taxon as G. cambogia var. papilla (Wight) T.Anderson. We could trace a specimen at K (K001273085) collected from Cochin, 'Wight no. 143, April 1848' and a duplicate specimen at L (L0012214) which is annotated as 'isotype'. The above-mentioned specimens 'Wight 143' cannot be considered as part of original collection as the date on specimens/sheets depicts that the collection is made after the description of taxon in 1845 . Original material of Wight's collection from Coonoor and Sispara could not be traced, therefore the illustration provided in the protologue as 'plate no. 960/2 (female)' is designated here as lectotype. The designated lectotype shows only the characters of female plant, but the precise identity of the male plant is based on stamen characters. The specimen 'Wight 143' at K (K001273085) is designated as epitype, as it has male flowering twig and further it is collected by the author himself.

Garcinia indica (Thouars) Choisy in DC., Prodr. 1: 561. 1824. Brindonia indica Thouars in F.Cuvier, Dict. Sci. Nat. 5: 340. 1806. Lectotype (first-step designated by Maheshwari (1964); second-step designated here): INDIA, s.loc., Du-petit Thouars s.n. (P030773 digital image!). Epitype (designated here): INDIA, Goa, 22.5.2018, Arun Prasanth R. \& V. Sundaresan 103 (MH!)

Fig. 2

Notes: Thouars (1817) published Brindonia indica Thouars. Choisy (1824) treated the taxon as Garcinia indica (Thouars) Choisy and mentioned that it is distributed in India. Maheshwari (1964) cited 'Type: Dupetit-Thouars s.n., India (PARIS)'. We could locate two ambiguous specimens of Dupetit-Thouars's P (P030772 and P030773). The sheet 'P030772' has a label by the author, fragment of stem without leaves, line drawing, male and female flowers in a packet. Whereas, sheet 'P030773' has label by author, fragment of stem, and packet containing male flowers. Though the locality of collection was not mentioned on the sheets, the database show that the collections were from Madagascar. Thouars (1817) while describing the taxon cited that 'the specimen is from India and its bark was taken to France with some seeds but its survival was unsuccessful'. Moreover, Perrier (1950) have not mentioned about its occurrence in Madagascar. Maheshwari (1964), Singh (1993) and 


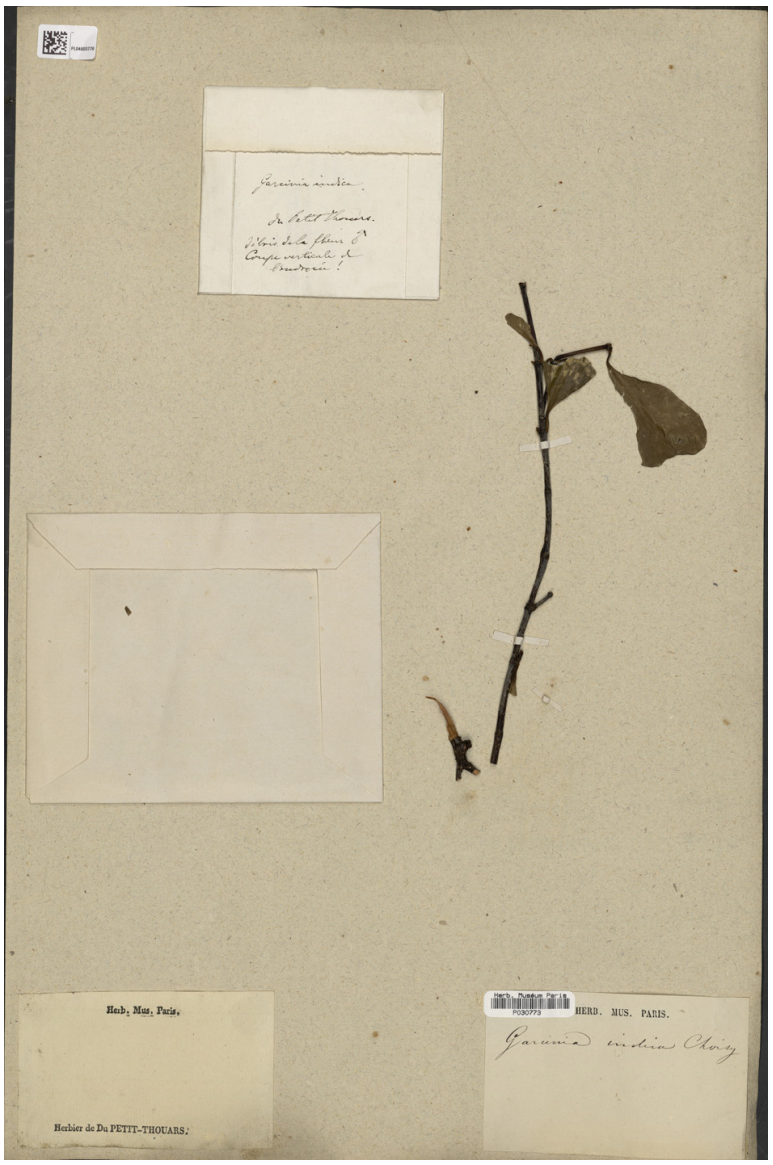

Fig. 2. Lectotype of Garacinia indica (Thouars) Choisy (Du-petit Thouars P030773) @ Museum National d'Histoire Naturelle, Paris.

Mabberley (2017) reported distribution of $G$. indica as endemic to India. Based on the above citations, it can be concluded that the specimens of $G$. indica at $\mathrm{P}$ is from India and not from Madagascar. Maheshwari's (1964) choice could be considered as first-step of lectotypification, since two sheets are available at $\mathrm{P}$. Though the specimens are ambiguous, being part of original collection one of the specimens with barcode P030773 is selected here as second-step lectotype. Since the diagnostic character is fruit, the specimen collected from the type locality 'Goa' by Arun Prasanth R. \& V. Sundaresan $103(\mathrm{MH})$ is designated here as epitype.

\section{Acknowledgments}

The authors are grateful to the Director, CSIRCIMAP, Lucknow for facilities and encouragement; curators of CAL, MH, A, E, L, K, G, BR, P and B for support; Dr. Mayur D. Nandikar (NGCPR); Shirwal and Dr. Varsha V. Nimbalkar (Department of Botany, Dr. Babasaheb Ambedkar Marathwada University, Aurangabad) for their valuable suggestions. The financial support from the DSTSERB funded project (EMR/2016/005433) is gratefully acknowledged.

\section{Literature Cited}

CHOISY J.D. 1824. Guttiferae. In: CANDOLLE A.P. DE (ed.), Prodromus Systematis Naturalis Regni Vegetabilis. Volume 1. Sumptibus Sociorum Treuttel et Wurtz, Paris pp. 561.

MABBERLEY D.J. 2017. Mabberley's Plant-Book: A Portable Dictionary of Plants, their classification and uses. Fourth edition. Cambridge University Press, Cambridge.

MAHESHWARI J.K. 1964. Taxonomic studies on Indian Guttiferae III. The genus Garcinia Linn. Bulletin of Botanical Survey of India 6: 107-135.

NOLTIE H.J. 2005. The Botany of Robert Wight. Regnum Veg. 145. A.R.G. Gantner, Ruggell. pp. 290-291.

PERRIER DE LA BATHIE H. 1950. Guttiferae. In: HUMBERT H. (ed.), Flora de Madagascar et des comores: plantes vascularies. Famille 136. Tananarive, Paris. pp. 49-61.

SINGH N.P. 1993. Clusiaceae (Guttiferae nom. alt.). In: SHARMA B.D. \& M. SANJAPPA (eds.), Flora of India. Volume. 3. Botanical Survey of India, Kolkata. pp. 86-144.

STAFLEU, F.A. \& R.S. COWAN 1988. Taxonomic Literature. Second edition, Volume. 7, W-Z, Scheltema \& Holkema, Utrecht, pp. 277.

THOUARS L.M.A.D. 1817. Botanique. In: CUVIER F. (ed.), Dictionnaire des Sciences Naturelles, Edition 2, 5. Strasbourg, F.G. Levrault, Paris. pp. 340.

TURLAND N.J., WIERSEMA J.H., BARRIE F.R., GREUTER W., HAWKSWORTH D.L., HERENDEEN P.S., KNAPP S., KUSBER W.H., LID.Z., MARHOLD K., MAY T.W., MCNEILL J., MONRO A.M., PRADO J., PRICE M.J. \& G.F. SMITH (eds.) 2018. International Code of Nomenclature for algae, fungi, and plants (Shenzhen Code) adopted by the Nineteenth International Botanical Congress Shenzhen, China, July 2017. Regnum Vegetabile 159. Koeltz Botanical Books, Glashütten. DOI https://doi.org/ 10.12705/Code. 2018

WIGHT R. 1839. Icones Plantarum Indiae Orientalis: or Figures of Indian Plants. Volume 1. J.B. Pharoah, Madras. p. 121.

WIGHT R. 1845. Icones Plantarum Indiae Orientalis: or Figures of Indian Plants. Volume 3(3). J.B. Pharoah, Madras. p. 960. 